\title{
EL PINTOR JUAN DE HERRERA Y UN CUADRO FLAMENCO EN LA CATEDRAL DE MEXICO
}

Juan de Herrera fue un pintor de la segunda mitad del siglo xvir mexicano. Su nombre evoca el del ilustre arquitecto de El Escorial, pero seguramente no hay ningún lazo familiar entre ellos. Un siglo de diferencia los separa. No sabemos, por ahora, nada de Juan de Herrera, salvo el nombre. Ni siquiera si fue español o mexicano. Es posible que sea mexicano por su decidida aceptación a la pintura criolla anterior - contemporánea a él, sin que denote preocupación especial por la pintura europea de su momento. Fue un discipulo fiel a la Escuela Colonial y si le buscáramos un maestro, lo encontraríamos en Cristóbal de Villalpando.

La obra de Juan de Herrera se reduce a las pequeñas pinturas de la Capilla del Santo Cristo de la Catedral de México. Seguramente son también de él cuatro b́leos, de mayor tamaño, que están en la Catedral de Texcoco. Se le cita en las historias de la pintura o en las monografías sobre la Catedral, pero casi siempre en plan muy secundario. Oveja perdida en el ancho campo de la pintura del virreinato, pretendemos rescatarlo y darlo a conocer en este breve estudio, acompañado de las magníficas fotografías que sacó para mi el señor Sergio March.

La primera mención que se hace de Juan de Herrera está en el famoso y hermoso Diálogo sobre la historia de la pintura, del ilustre intelectual conservador licenciado don Bernardo Couto. En este diálogo, como es sabido, hablan el poeta José Joaquín Pesado, el pintor Pelegrin Clavé y el propio Couto. Dicen:

Pesado: Pues por lo que veo, hubo en México no corto número de pintores del siglo xvir.

Couto: Aún nos falta mostrarte algo de los Rodriguez Juárez, que lo cerraron dignamente y que dieron principio a una nueva edad de la pintura entre nosotros. Pero antes quiero decirte que del mismo siglo xvi conozco, además de otros oscuros, algunos que, por su mérito, te nombraré. Sea el primero Juan de Herrera, a quien nuestros antepasados llamaron el "divino", como 
en España a Luis Morales, o porque sólo se ejercitaba en asuntos sagrados o por la perfección con que los desempeñó. En la Capilla de las Reliquias de la Catedral hay, en el altar principal, doce cuadritos firmados de su nombre, con fecha de 1698, que representan santos mártires, bien acabados y de bastante gusto.

Clavé: Tengo muy presente que, cuando los vimos, nos dejaron algún sabor de estilo holandés. 1

Hay un error en este párrafo de Couto que corrigió don Manuel Romero de Terreros, Marqués de San Francisco, al advertir que el absurdo adjetivo de "divino" - así sea en Luis Morales o en cualquiera- se le dio, no a Juan de Herrera, sino a fray Alonso López de Herrera, pintor dominico de principios del siglo xvir.

Añade Romero de Terreros que los cuadros de las gavetas de la Capilla "no carecen de mérito, ciertamente, pero son muy inferiores a cualquiera de las pinturas de Alonso López de Herrera." 2

Entre Couto y Romero de Terreros hay que recordar a don Manuel Rivera Cambas, quien en su precioso libro México pintoresco, artístico y monumental, de 1880, habla dicho que en la Capilla de las Reliquias "hay algunos cuadritos de mérito artístico representando escenas de los mártires de la Roma pagana". Habló de oídas, pero no quiso olvidar èsos cuadritos, que no todos son de la Roma pagana.

El maestro Manuel Toussaint dice en su Pintura colonial de México, escrita en la década de los treintas, transcribiendo a Couto: "Efectiva. mente, esos cuadros revelan a un artista estimable." En La Catedral de México repite que los cuadros "únicamente son estimables" y en el Arte colonial en México lo reitera, añadiendo que también son "graciosos". ${ }^{3}$

Don Agustín Velázquez Chávez reproduce la corrección de Romero de Terreros y añade: 'Los cuadros más antiguos de que tengo noticiá son los de la sacristfa del convento franciscano de Texcoco, fechados en 1696." Y como juicio crítico: "Desde luego los cuadros son inferiores a los de López de Herrera; otro es su dibujo, su colorido, y no hay en

1 El Didlogo de Couto fue escrito en 1860, pero se publicó hasta 1872, por el editor Escalante; después, en 1898, por Victoriano Agüeros y en 1947 por el Fondo de Cultura Económica, con prólogo y notas de Manuel Toussaint.

2 El pintor Alonso López de Herrera. Primera edición, 1934, Ed. Cultura. Segunda, en Anales del IIE, No 34.

8 La pintura colonial de México se publice hasta 1962 por el Instituto de Investigaciones Estéticas, UNAM. El arte colonial on 1948, por el mismo Instituto, con tegunda edición en 1965, y La Catedral de México en 1947, en edición de la Mitra. 
ellos esa grandiosidad de inspiración, ni la elocuencia pictórica de los del divino Herrera; revelan la buena tradición de la escuela mexicana del siglo xvir sus transparencias doradas y azules." 4

Hizo muy bien Velázquez Chávez en hablar, al propósito de Herrera, de la escuela mexicana colonial del siglo xvir, asf como en observar las aplicaciones doradas y las veladuras - que no transparencias- azules que gustó poner en sus óleos el pintor. De la "escuela mexicana del siglo xvir" hablaremos después.

Debemos citar también al señor canónigo don Pablo de Jesús Sandoval, quien al referirse a la Capilla dice: “(Hay) doce pequeñas pinturas de santos mártires, de Juan de Herrera, llamado el 'divino', cuya firma se ve en la que representa a San Primitivo; una con esta fecha: 98, corona el rico ornamento de este altar." Ignoramos qué quiso decir con la última frase. El señor Sandoval crela que este Herrera era el "divino", como setenta y ocho años antes lo creyó Couto. De nada sirvió la corrección de Terreros, hecha cuatro años antes de que apareciera el libro La Catedral de México, con textos del citado señor Sandoval y de otro canónigo: Ordóñez. 5

Respecto de los cuadros de Texcoco que cita Velázquez Chávez, están, desde hace años, colocados entre las ventanas de los cruceros, arriba de la cornisa (l), por lo cual es imposible estudiarlos y fotografiarlos. No puedo asegurar ninguna autenticación, ni menos una crítica. Son: San Francisco; San Francisco y un ángel; Glorificación de San Francisco y Santo Domingo.

La Capilla del Santo Cristo o del Cristo de los Conquistadores o de las Reliquias, es una de las más antiguas de la Catedral, terminada

4 Tres siglos de pintura colonial mexicana, editorial Polis, 1939. Don Diego Angulo, en su Historia del arte hispanoamericano, 1950, tomo $\mathrm{u}, \mathrm{p}$. 424, transcribe los datos de Velázquez Chávez.

- Este libro se publicó, por primera vez, en 1938. Al afio siguiente, don Manuel Toussaint, en el vol I de los Anales del Instituto de Investigaciones Esteticas hizo una dura y justa crítica de los innumerables errores del libro. De nada sirvió, pues 
en 1615. Conserva su bóveda gótica de crucería. El retablo mayor tiene dos épocas. El nicho en que está el Santo Cristo parece ser de mediados del siglo xvir, del retablo más antiguo. La base y las alas laterales son del siglo xviri, en fecha que no tenemos exacta.

El gran Crucifixo, mal llamado "de los Conquistadores", según la leyenda, fue un regalo a la Catedral de Carlos V. Es de tamaño natural, de buenos miembros y proporciones, pero no es una obra de arte sobresaliente. Dada la espléndida imagineria española desde siempre, este Cristo es más importante por su antigüedad que por su belleza artistica.

A la vez que para el culto del Santo Cristo, que llamaron de los Conquistadores por creerse que llegó poco tiempo después de la toma de Tenochtitlan, pero que nada tiene que ver con las huestes de Cortés, esta Capilla es el relicario de la Catedral, por lo menos desde 1698 en que se le pidieron a Herrera sus pinturas.

La grandiosa reja de madera, de la entrada, fue de las pocas que respetó el siglo xIx, pues como se sabe, las sustituyó por unas caricaturas de rejas de metal, de unos dos metros de altura, como si fueran de un jardín doméstico. El señor arzobispo Luis María Martínez enmendó la torpeza y cerró las capillas con sus rejas de madera como estaban, tan admirablemente labradas que parecen coloniales. Fue una rehabilitación que honra mucho al ilustre prelado.

En el intradós del arco están unas pinturas de Bentura Miranda. Este pintor, medianísimo, floreció en el siglo xvin. En 1723 valuaba los cuadros de una testamentaria, según dice Toussaint, y añade que "de él se conservan unos lienzos en el areo que da entrada a la Capilla de San Pedro, en la Catedral (léase Capilla de las Reliquias) con personajes bfblicos". Toussaint conservaba "un cuadrito suyo, con una mala copia de la Virgen del Altar del Perdón, a la que ha agregado a San Joaquín".

Los personajes bfblicos son Moisés, Salomón, David y Zacarías, cada uno con sus textos de la Sagrada Escritura. En el lado derecho del espectador, o de la Epistola, hay un pequeño retablo, de fines del siglo xvirl, con una Purisima en pintura y un San José de escultura. Los cuadros que lo rodean se refieren a los últimos actos de la pasión de Cristo. En el nicho central se conserva aún una hermosa Sagrada Fa-

en la segunda edición, de 1943, con todo y prologo de Alberto Marla Carrefio, los disparates quedaron en su lugar.

- La pintura colonial, op. cit., p. 145. 
milia, en marfil, procedente de Filipinas. Del lado izquierdo o del Evangelio, otro retablo del siglo xvil se incrusta en el nicho renacentista que, originariamente, debió servir -como en las demás capillas- para sepulcros de arzobispos. Es un retablo guadalupano, con su pintura central de 1737, obra de José de Ibarra.

Las pinturas de Juan de Herrera están en la base o predela del retablo principal, predela excepcional por su altura, ya que fue pensada para contener en sus nichos las reliquias. Alternan los cuadros con cuatro esculturas de ángeles que sirven de base a las columnas del retablo.

Es lógico pensar que al santo o a los santos representados en las tablas de pintura correspondan las reliquias guardadas y asł debió ser en 1698. Pero de entonces a acá ha habido muchos cambios, debidos a nuevas reliquias, a los despojos del siglo xix -el primero el de don Juan José Baz- y a caprichos posteriores. Veamos los datos que nos dan Marroqui, en 1904 y los muy diferentes de Sandoval, en 1938. Seguimos el orden de izquierda 2 derecha.

San Abundio: "El nicho parece destinado a sólo tres santos, San Abundio, San Basso y San Palmario (Palmasio), pues en la puerta de él se ven pintadas las imágenes de los tres y dentro se guardan una canilla de cada uno de ellos." (Marroqui.) "Una urna de vidrio con un fémur completo de San Atanasio (léase Anastasio) y la cabeza del mismo mártir esculturada. Una custodia con fragmento de fémur de San Inocencio." (Sandoval.)

San Epigmenio: "Un relicario de madera dorada con una canilla del mismo santo... un hueso de San Felipe de Jesús... reliquias de San Aniceto y San Julio, Santa Irene, San Casiano, Santa Inés, San Cleto... un busto de plata sobredorada... un marco de plata en que están unas dimisorias para órdenes del presbitero Pedro Sánchez firmadas por San Francisco de Borja..." (Marroqui.) "Un Sanctum Lignum... pequeñas reliquias de San Pedro y San Pablo. Cráneo de San Máximo; un hueso de San Hilarión y otro de San Cornelio, Papa ... fémur de San Mauricio y otro de San Tito... un hueso de uno de los innumerables mártires de Zaragoza... unas letras dipsomas (sic) de San Francisco de Borja ..." (Sandoval.) 
San Felipe de Jesús: "Custodia de plata sobredorada con un hueso y un pedazo de hábito del santo. Otra custodia con un pedazo de velo de la Santísima Virgen, otro de la capa de San José y huesitos de San Francisco Javier, San Francisco Regis, San Ignacio de Loyola, San Francisco de Borja, San Luis Gonzaga y Santa Rosa de Lima. Urna de plata con huesos de San Cornelio y de los santos Adriano, Tito, Mauricio y Honorato, etcétera (Marroqui) "No contiene nada." (Sandoval.)

San Primitivo: "El esqueleto desarmado de dicho santo en una urna de plata con cristales." (Marroqui.) "No hay reliquias bajo la pintura de San Primitivo." (Sandoval.)

San Gelasio: "Urna de plata con hueso de San Gelasio; una cabeza y dos huesitos de las once mil vírgenes. Un hueso de San Anastasio, otro de Santa Cándida y dos de San Vito." (Marroqui.) "Esqueleto completo de Santa Hilaria." (Sandoval.)

San Anastasio: "Una cabeza de madera de San Pablo". (Marroqui.) "Huesos de San Urbano y San Severiano y San Justino... parte de la cabeza de San Juan B. (¿Bautista?) ... el fémur de San Palmacio, cónsul, y parte de la tibia de San Abundio..." (Sandoval.)

- Juan Diego y Zumárraga: "Relicario de plata con hilos de la tela en que está pintada la Virgen de Guadalupe... dos relicarios con huesos de santas vírgenes y mártires..." (Marroqui.) "Húmero de San Torcuato; dos cóndilos del fémur de los santos (sic) Armando y Benedicto con auténtica de 1790 ... pequeñísimas reliquias de Santa Marfa Magdalena, San Luis Gonzaga, San Estanislao..." etcétera. (Sandoval.)

San Pedro Mártir: "Un relicario de madera dorada con una canilla del mismo santo y otro igual con canilla de San Teodoro." (Marroqui.) "Cráneo de Santa Cordula, socia de Santa Úrsula." (Sandoval.)

Santa Gaudencia: Marroqui no dice nada. "Un cráneo y fémur quebrado, completo, de las once mil virgenes (sic) ... huesos de San Adriano, Modestino, Vito, Inocencio, Cándida, Ricardo, Santa Sirena, de San Gelasio de los Santos Inocentes y un (sic) occipital de San Felipe Neri..." (Sandoval.) Notemos que el señor Sandoval dice que "habia" esas reliquias en ese nicho.

Santa Hilaria: Marroqui nada dice. Sandoval afirma que el nicho está vacío.

San Vito: "Cráneo de Santa Pinosa y huesos de San Zenón, Clemencia, Mauricio, Onusta (por Venusta) ..." (Sandoval.) 
Santa Ursula: "Cráneo de San Mauricio y cuerpo de Santa Genoveva ..." (Sandoval.)

Como se ve, no puede haber mayor confusión. *

La "escuela" mexicana de pintura del siglo xvir es la más importante del virreinato. Juan de Herrera, pintando a fines del siglo, tenia antes de él unạ pléyade de importantes artistas de los cuales tuvo que gozar -no sé por qué ha de ser "sufrir"- la influencia. Desde luego la imponente familia de los Echave: Baltasar de Echave Orio -antes "el viejo"Baltasar de Echave Ibia, su hijo -antes "el joven"- y Baltasar de Echave Rioja. Esos tonos azules de que se habló antes pueden deberse a Echave Ibía, a quien justamente llamó Toussaint el "Echave de los azules". Después Luis Juárez y su hijo José, diferentes y personalísimos. El magno y aun de no aclarada obra pictórica, Sebastián de Arteaga, Pedro Ramfrez. Hipólito de Rioja, pintor con el que tiene espirituales vecindades Herrera. Juan Sánchez Salmerón. Los Correa. Los Rodríguez Juárez. Juan de Villalobos, Antonio de Santander, Diego de Borgraf y Juan Tinoco, en Puebla, Y, por fin, como magnífica cumbre, Juan Correa y Cristóbal de Villalpando.

Yo veo la mayor influencia en Echave Ibia, Hipólito de Rioja, Juan Correa y, sobre todo, Cristóbal de Villalpando. Lo llamé, al principio, discipulo de Villalpando y creo que es exacto, pero como en Rioja, los temas de Herrera son de martirio y sus cuadros son pequeños y escasos. De Rioja toma ejemplos para sus personajes y trajes, sus colores y sus carnaciones. Sin embargo, son diferentes. Rioja gozaba con pintar multitudes de personas y ángeles rodeando a sus mártires. Herrera va directo a su modelo y no quiere distracciones en torno.

Como Luis Juárez y sus nietos, los Rodríguez Juárez, el pintor Herrera hace resplandecer en oros las aureolas de sus santos a base de concentraciones simétricas de rayos, separadas unas de otras para que no formen una plasta. Sus áureos rayos son finísimos, unos más largos que otros, como estallidos luminosos.

- En la Gaceta núm. 12, de noviembre de 1728 se enumeran las siguientes reliquias de la Catedral: el cuerpo de San Primitivo, el de Santa Hilaria, dos cabezas de las once mil virgenes, cabeza de San Anastasio, de San Gelasio, de San Vito y otras. 
Mas la mayor influencia proviene de sus compañeros en la obra artística de la Catedral, como se ha dicho: Juan Correa y Cristóbal de Villalpando. De Correa parten esas manos de alargados dedos, terminados en punta, desdibujados, esqueléticos. De Villalpando son los atuendos de las figuras, las joyas, las sedas y brocados. Es más, las propias figuras están inspiradas en Villalpando, con sus grandes ojos, sus facciones irregulares, sus cabellos ensortijados. Tampoco puede olvidarse la lección de Juan y Nicolás Rodríguez Juárez.

El San Abundio y la Santa Úrsula podria haberlas firmado con gusto el gran pintor de la sacristía catedralicia. Como Villalpando, en fin, Juan de Herrera tiene esa "variedad ejecutiva" que se dijo de Valdés Leal. 7

Juan de Herrera no es un copista, aunque si un ecléctico que resume las técnicas y los resultados de sus antecesores y contemporáneos. Es fiel a su medio y a su momento. Aprovecha lecciones. Gusta tomar lo mejor y acepta la superioridad artistica de los maestros del siglo xvir, se suma a ellos y nos da una obra sincera y emotiva, a pesar de varios defectos.

Don Manuel Toussaint se empeñó en considerarlo como "estimable" y tiene razón, pero recordemos que todo adjetivo admite grados, salvo los adjetivos absolutos. Yo dirfa que es "muy" estimable; que es un buen pintor de su tiempo y casi a la altura de sus antecesores y contemporáneos; tiene suficientes méritos para estar muy cerca de ellos. Todo ello, por supuesto, dentro de la modestia de nuestra pintura colonial.

Es más, su nota personal y diferencial es su acendrado "tenebrismo". A partir de Caravaggio y del Españoleto se inició ese movimiento pictórico llamado "tenebrista" porque los fondos son oscuros y de ellos emergen las figuras con una luz especial para ellas, proyectada hacia ellas, luz artificiosa, artística, plena de sentido, luz que emana de la paleta del pintor y que no pretende imitar, ni le interesa, la luz natural. Juan de Herrera destaca sus figuras de un fondo totalmente negro para que sean ellas solas el objeto óptico, sensorial y definitivo de la pintura. Sólo dos veces usa paisaje: uno en el San Anastasio y otro en el San Felipe de Jestis.

No es un gran dibujante, pero sus figuras son dignas y elegantes. Sus colores son vivos, vibrantes, subrayados por las tinieblas de los fondos

7 Francisco de la Maza. El pintor Cristobal de Villalpando. Ed. del INAH, 1964, p. 19. 
y, como se ha dicho, usa mucho las coloraciones azules, grises y plateadas, sus preferidas. Ese "sabor holandés" que vio Couto no lo creemos justificado. Es, simplemente, la tradición española con sus influencias flamenca e italiana.

Respecto de los cuadros de la Capilla de las Reliquias, digamos, para empezar, que son once y no doce. Una de ellas fue sustituida en el siglo xvill por la conocida escena de Juan Diego ante Zumárraga. Digamos, también, que han sido retocados, aunque no en las figuras de los santos; repintados en algunos trozos, y que los letreros con los nombres de los santos, salvo en dos de ellos, han sido rehechos, borrando la pequeña y discreta grafía de Herrera por otra mayor y bastante burda. Además, han sido cambiados. Herrera los numeró de 1 a 6 para cada lado del altar, pero los números no se avienen con los sitios actuales.

Los marcos tampoco son los originales. Son obra del siglo xvir, obligados a la forma de ochavos irregulares que, incluso, casi ocultan el año del cuadro que está firmado y fechado. Están pintados directamente sobre la madera y miden, aproximadamente, 50 × 25 centímetros.

Veamos ahora, a fuer de prolijos, las once pinturas de Juan de Herrera, en un orden selectivo y no locativo.

1. San Abundio, San Basso y San Palmasio. Los letreros que lleva, enormes y de mal gusto, son, como se ha dicho, posteriores. Apenas si tocaré la hagiografía, porque los estudios iconográficos son muy escasos en México y, estéticamente, no importan los personajes como historia, sino como arte. Además, no es fácil concordar los datos con las imágenes. Hay, por ejemplo, ocho San Abundios, entre ellos el obispo de Como, en Italia, que no fue mártir. Por otra parte hay dos San Bassos, a uno de los cuales, después de otros tormentos, "lo atravesaron con dos. enormes clavos, con los que murió el año de 253".

Resulta que, para Herrera, San Abundio es un simple clérigo, joven y de tierno rostro, con su negra sotana y su bonete a la manera del siglo xvir. En cambio San Basso es el que lleva los clavos de su martirio en la mano derecha y es un espléndido obispo cuyas facciones recuerdan 
al Cardenal Richelieu. San Palmasio, mártir ignoto, es un sacerdote de edad madura con la palma en la mano. Es una figurita desdibujada que, aunque parece de la mano de Herrera, puede ser un agregado posterior.

El obispo San Basso es, como deciamos, espléndido, pues viste de pontifical, con su roja sotana, su alba sobrepelliz y capa pluvial de brocado con un broche pectoral enjoyado. Sus ojos son enormes, inteligentes y bondadosos; recta nariz y breve barbilla en punta. Es una de las mejores pinturas de Herrera.

2. San Primitivo. El nombre del santo lleva la grafia antigua, discreta, del propio Herrera. La firma del pintor está abajo, a la derecha: "Jn (Juan) de Herrera ft (fecit) año de 98 (1698)." El santo mártir (hay tres, todos de España) viste de peregrino, con su pobre pelliza femoral, y ha dejado en el suelo su sombrero y su báculo. Dos verdugos, con vestidos rotos pero de buenas telas, lo golpean con poderosas varas. Ambos llevan su camisa y jubón, sus gregüescos o pantalones cortos acuchillados, medias y calzas caídas. La palma del matirio cae recta del cielo.

3.San Gelacio. Fue este varón Papa y martir, del siglo v. Sin embargo, Herrera le coloca vestiduras sacerdotales y tiara del siglo xv. El verdugo, bien vestido pero con desaliño, se prepara a cortarle la cabeza con un alfanje; para ello le aparta la cabeza con su mano izquierda, mal pintado el escorzo, como siempre en los pintores coloniales. La escena es atroz, pero la gran figura pontificia, llena de oros y blancos, hace olvidarla.

4. Santa Gaudencia. Le gustó a Herrera el poner de rodillas a sus victimas y así lo hace con Gaudencia, santa desconocida. Es una hermosa dama, joven, rubia, ricamente vestida, incluso con doble collar de perlas, así como otra perla, enorme, engalana su hombro. Princesa fue, seguro, Santa Gaudencia. El verdugo la toma innoblemente de los cabellos para asegurar el tajo en el cuello, cosa que hace incluso con morboso deleite.

5. San Vito. Este santo es muy conocido por ser patrono y curandero del "baile de San Vito", esa especie de epilepsia que parece que ha desaparecido del mundo. Vito fue un adolescente de doce años de edad que murió, según la leyenda, en tiempos de Diocleciano. A pesar de que 


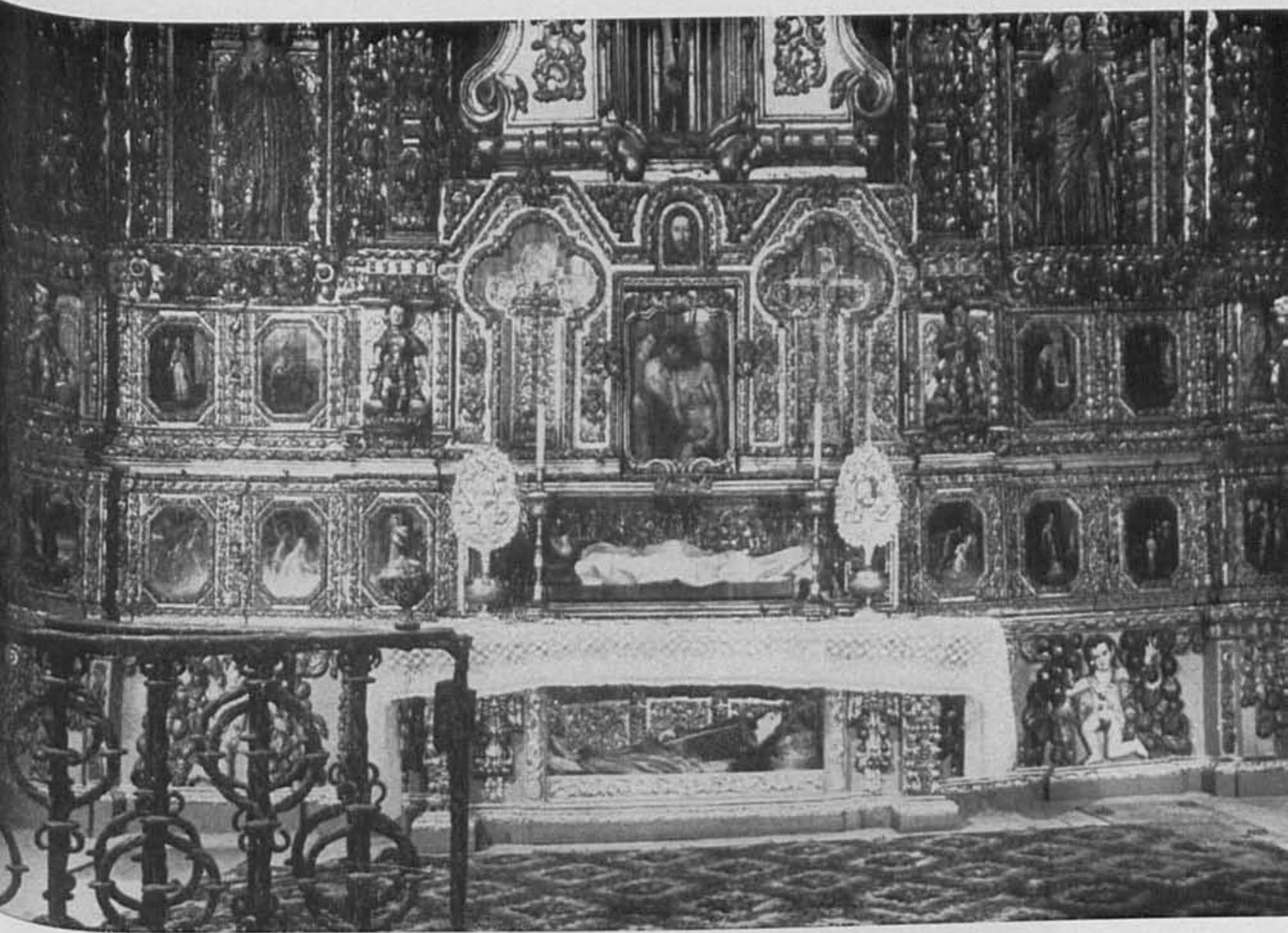

1. Catedral de México. Capilla de las reliquias. Foto S. March. 


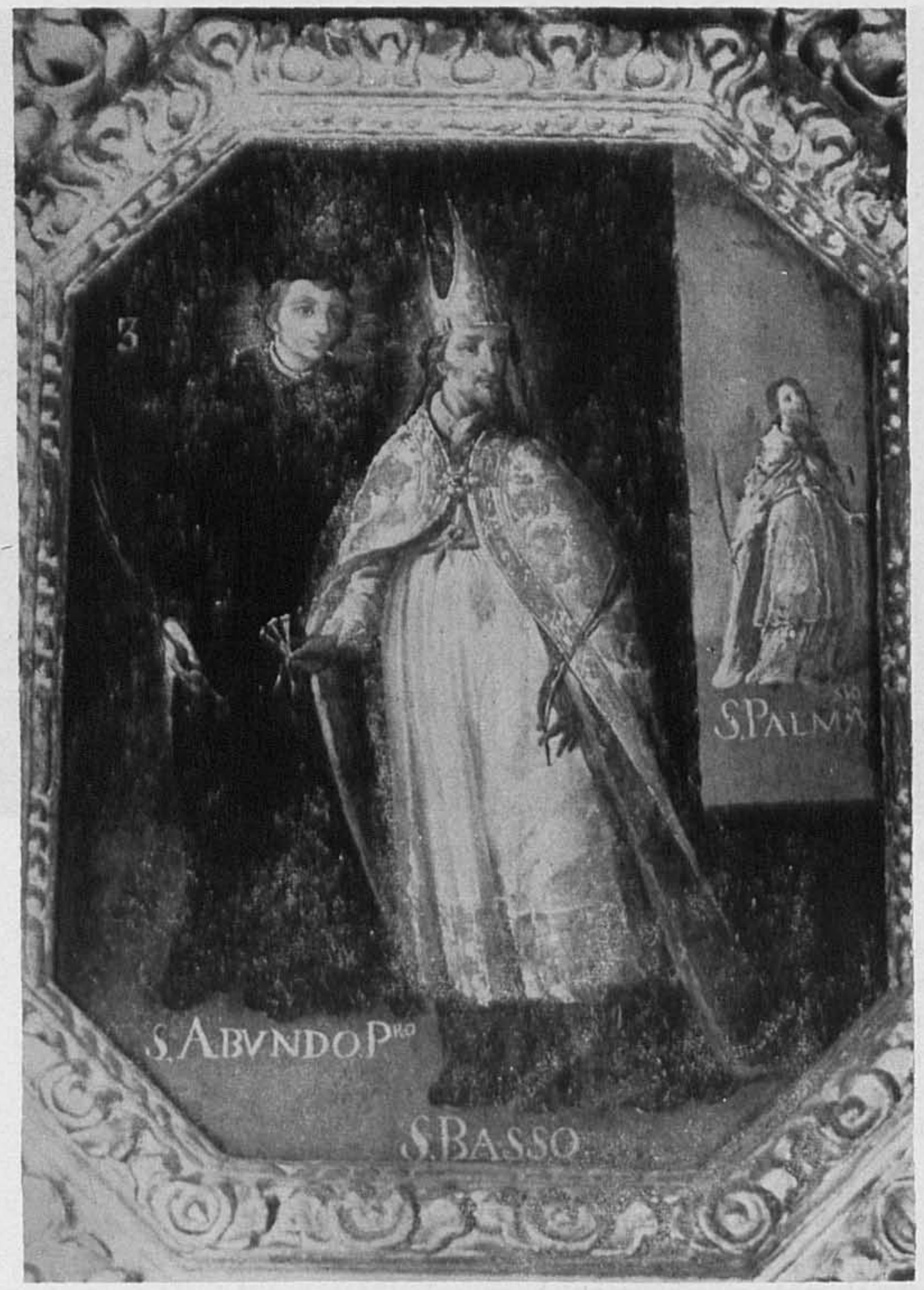

2. San Abundio, San Basso y San Palmasio. Foto S. March. 


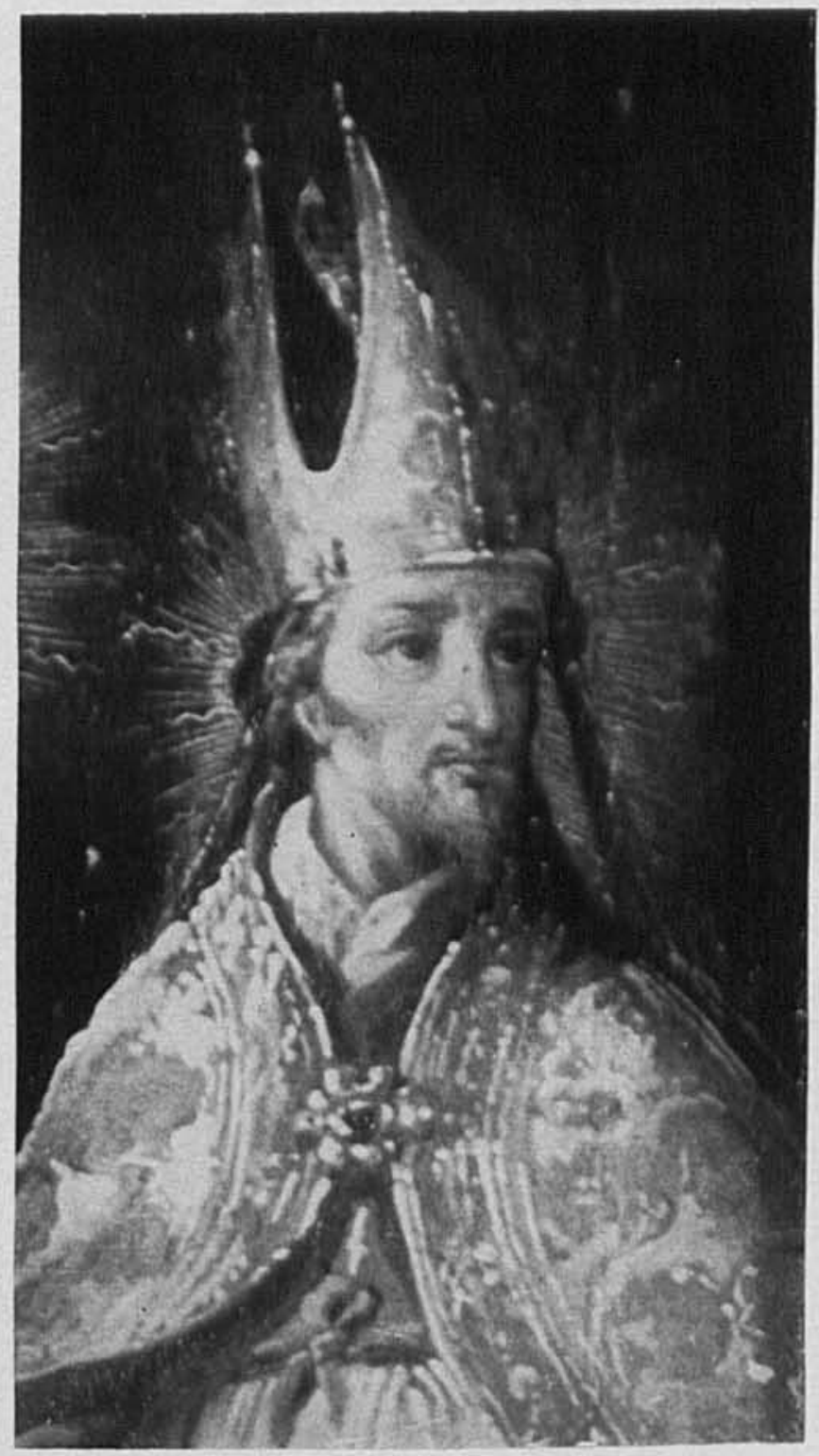

3. San Basso. Detalle. Foto S. March. 
DOI: http://dx.doi.org/10.22201/iie.18703062e.1972.41.963

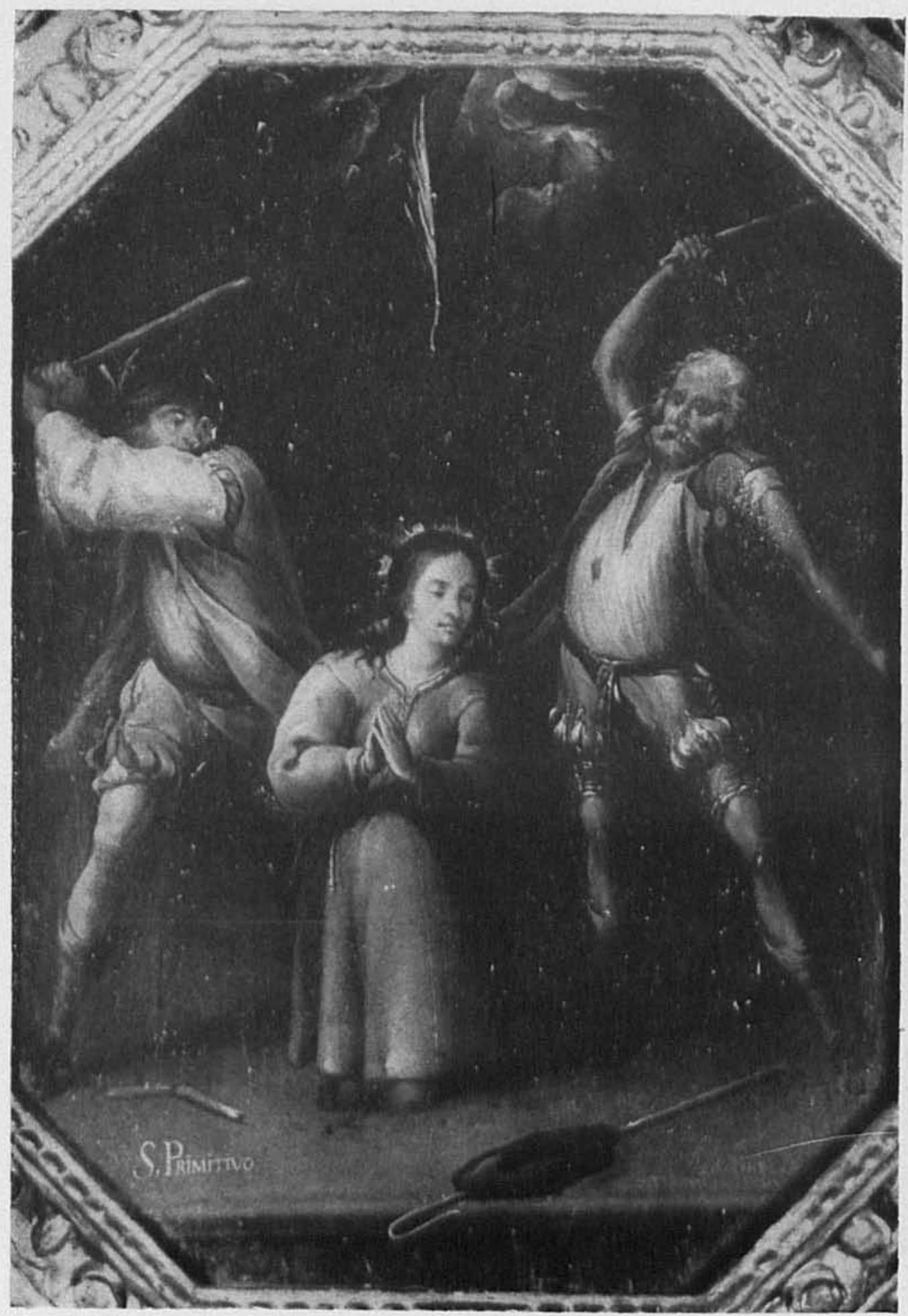

4. San Primitivo, Foto S. March. 
DOI: http://dx.doi.org/10.22201/iie.18703062e.1972.41.963

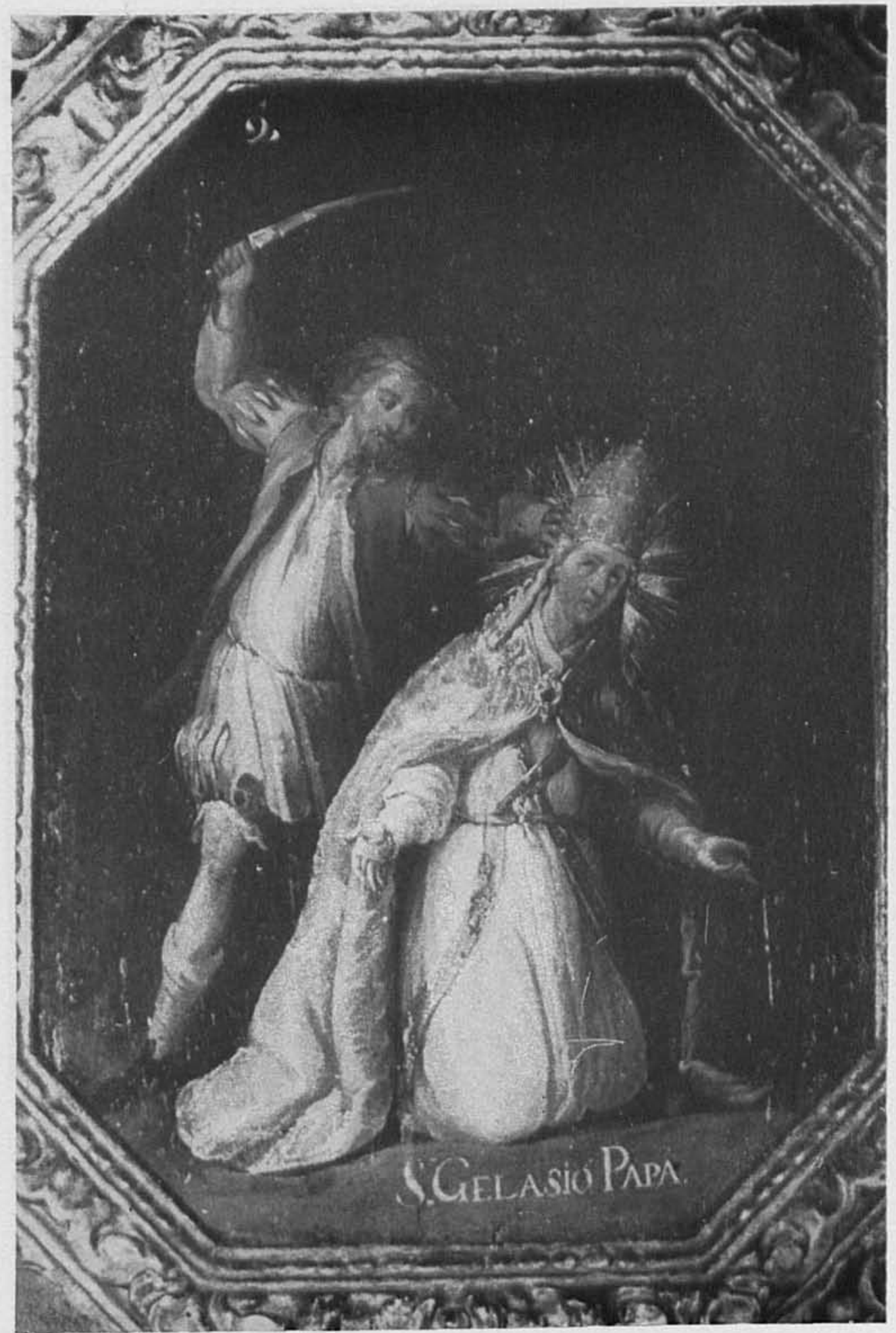

5. San Gelasio. Foto S. March. 
DOI: http://dx.doi.org/10.22201/iie.18703062e.1972.41.963

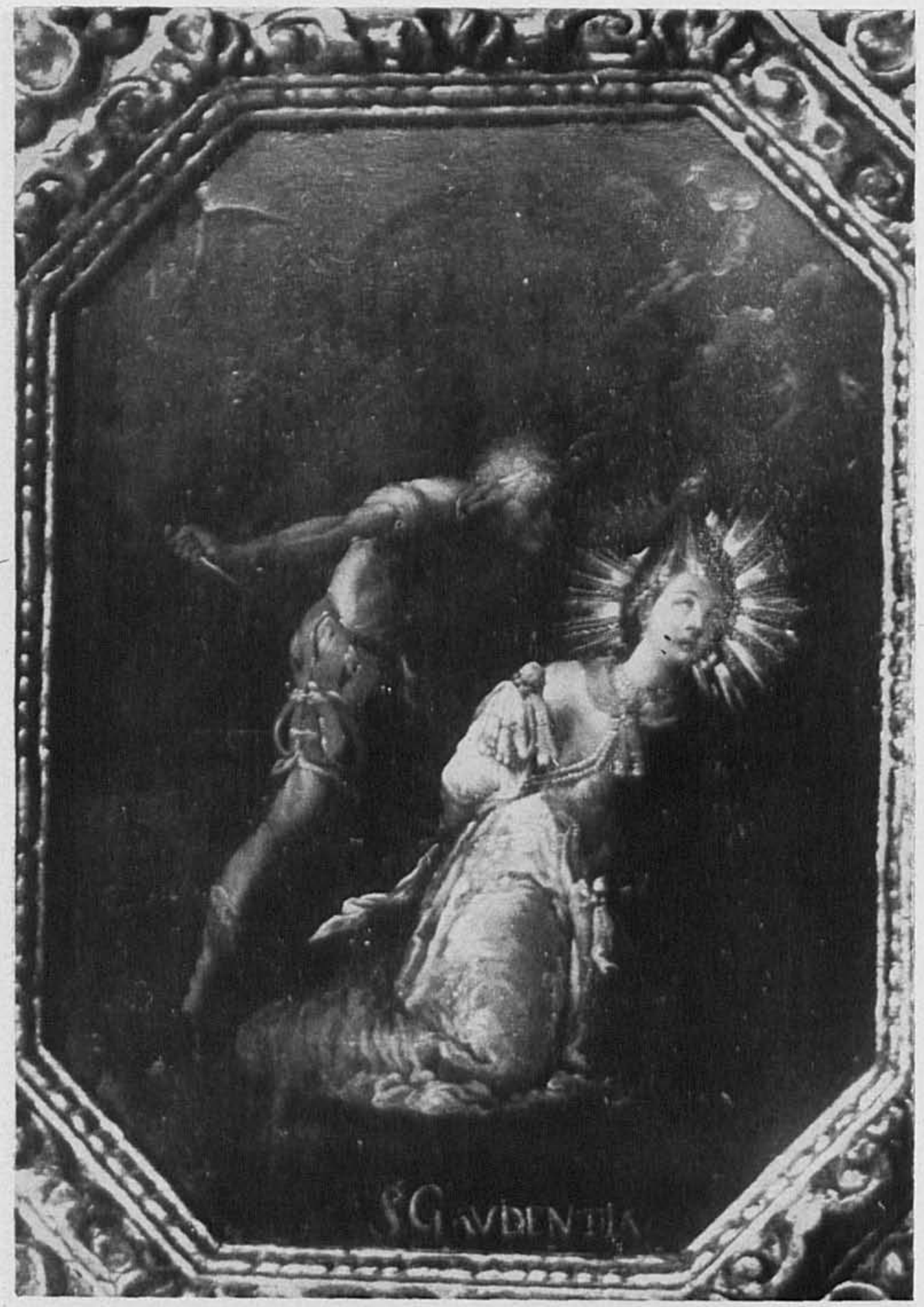

6. Santa Gaudencia, Foto S. March. 
DOI: http://dx.doi.org/10.22201/iie.18703062e.1972.41.963

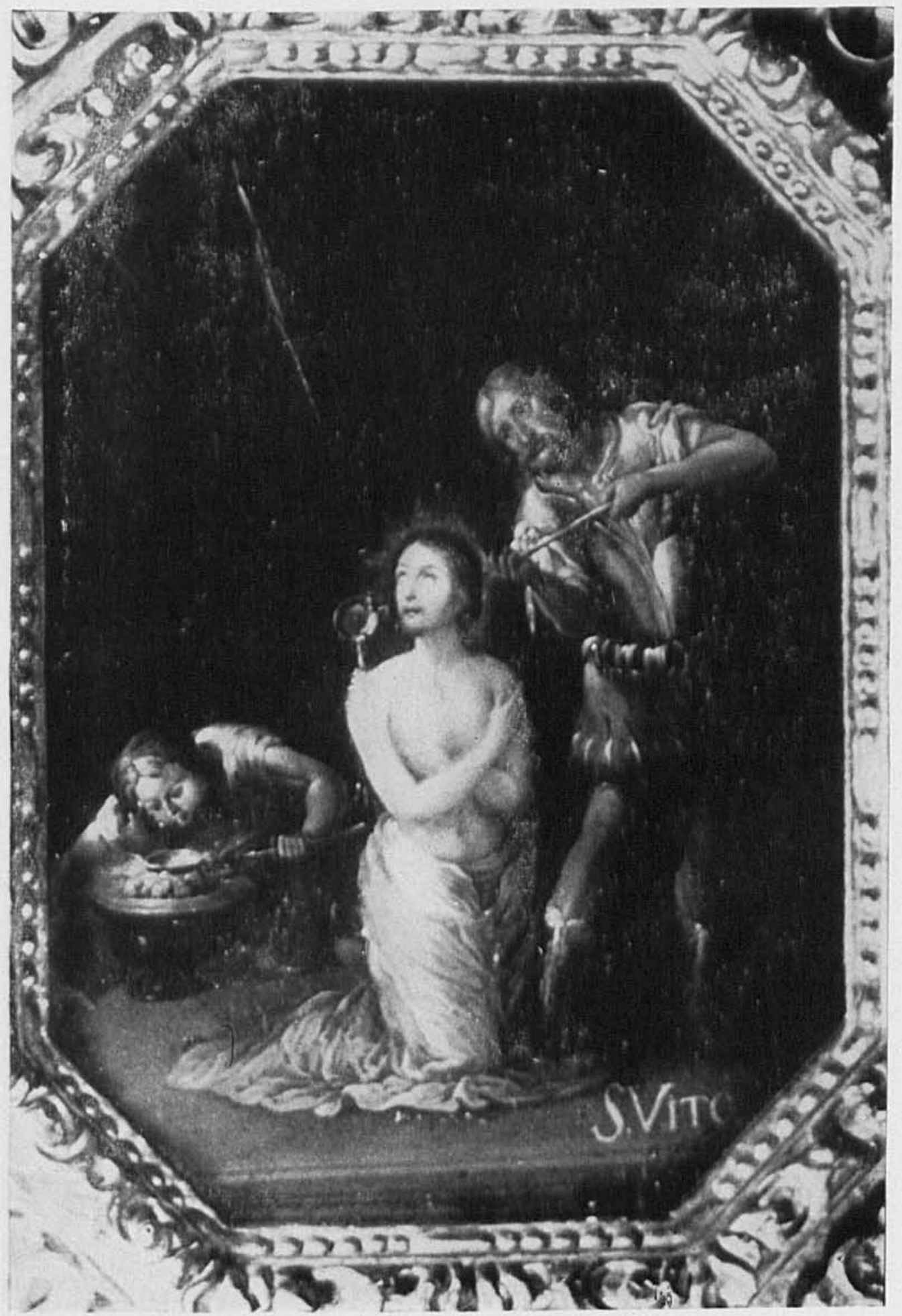

7. San Vito. Foto S. March. 
DOI: http://dx.doi.org/10.22201/iie.18703062e.1972.41.963

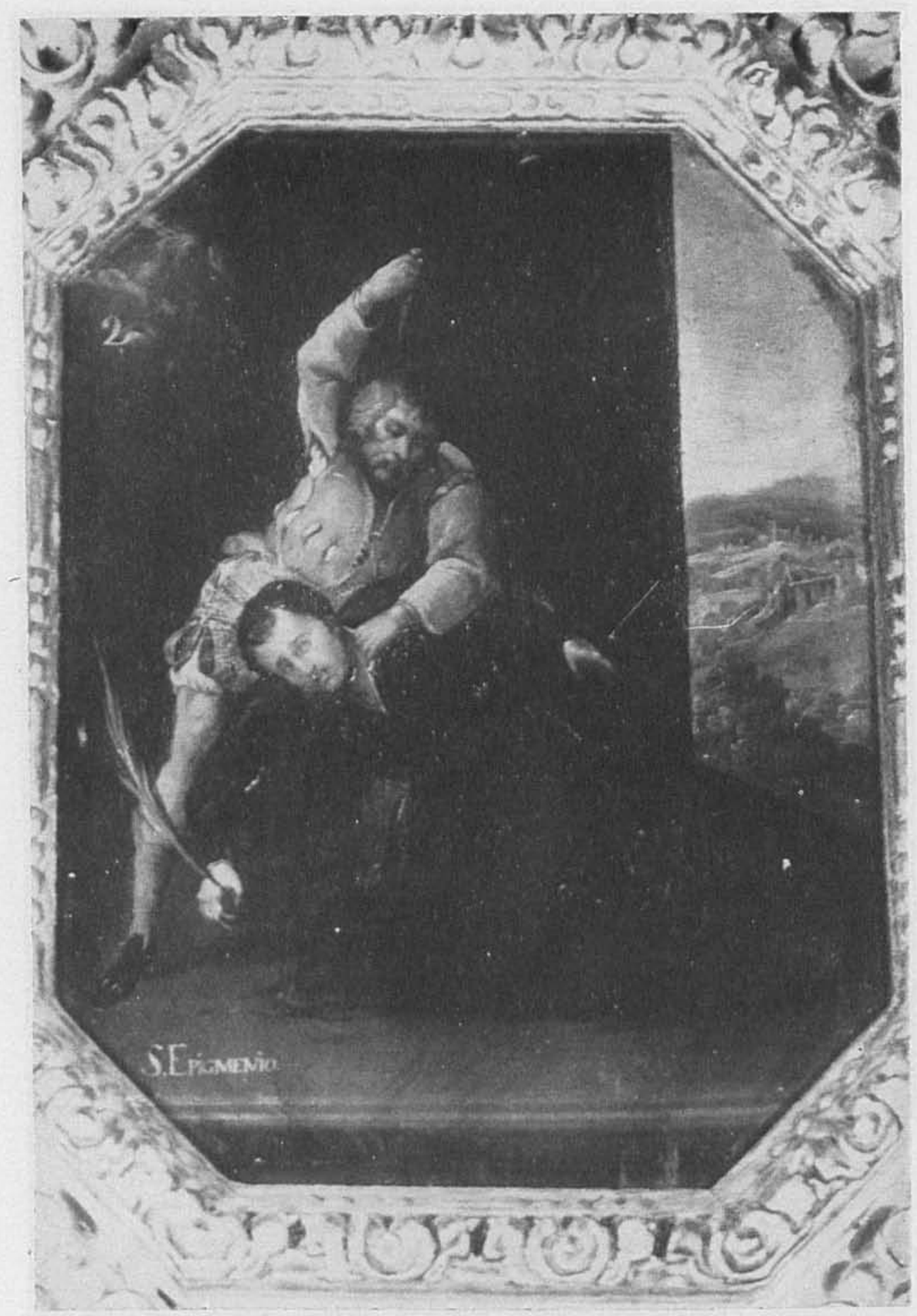

8. San Epigmenio. Foto S. March. 
DOI: http://dx.doi.org/10.22201/iie.18703062e.1972.41.963

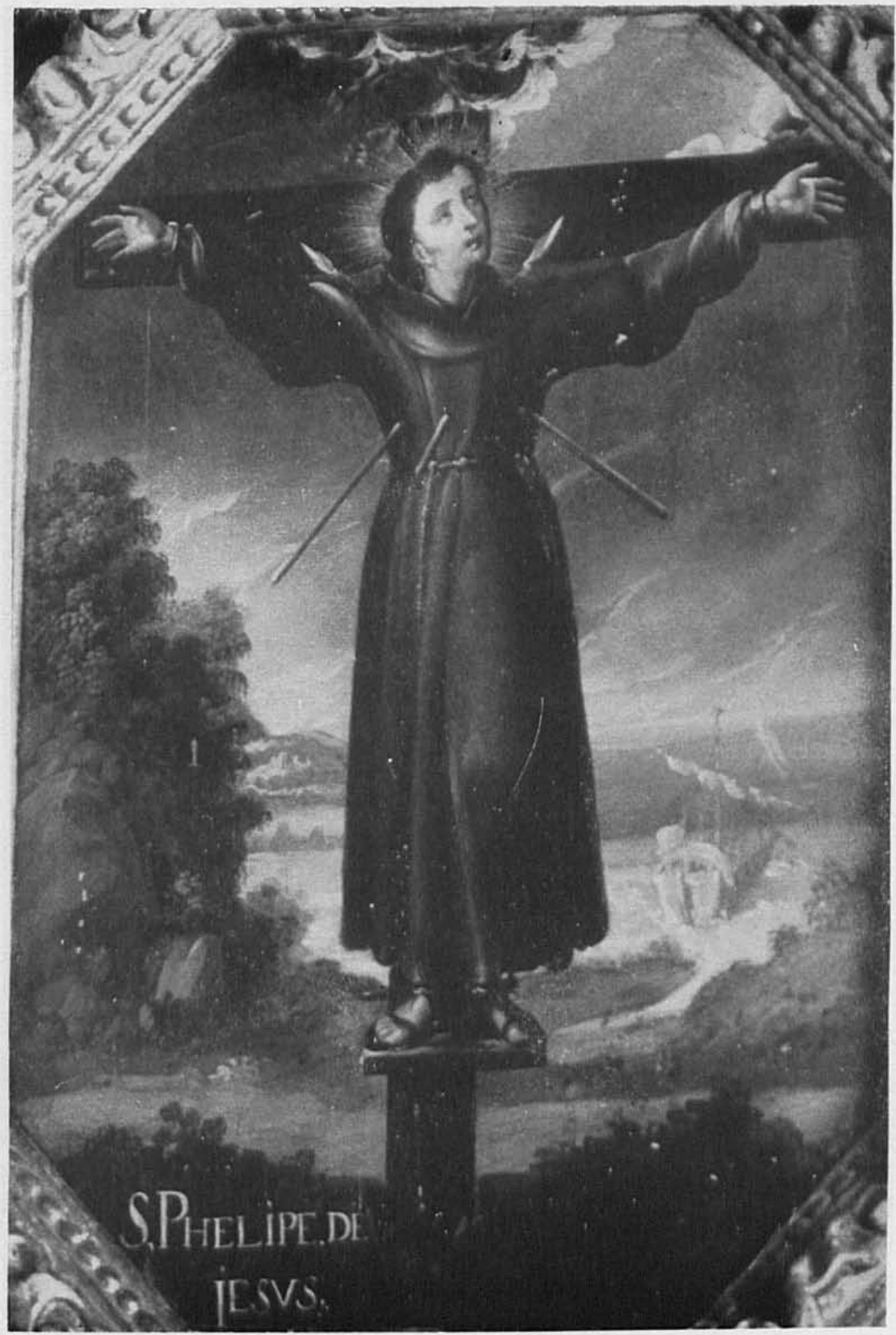

9. San Felipe de Jesús. Foto S. March. 


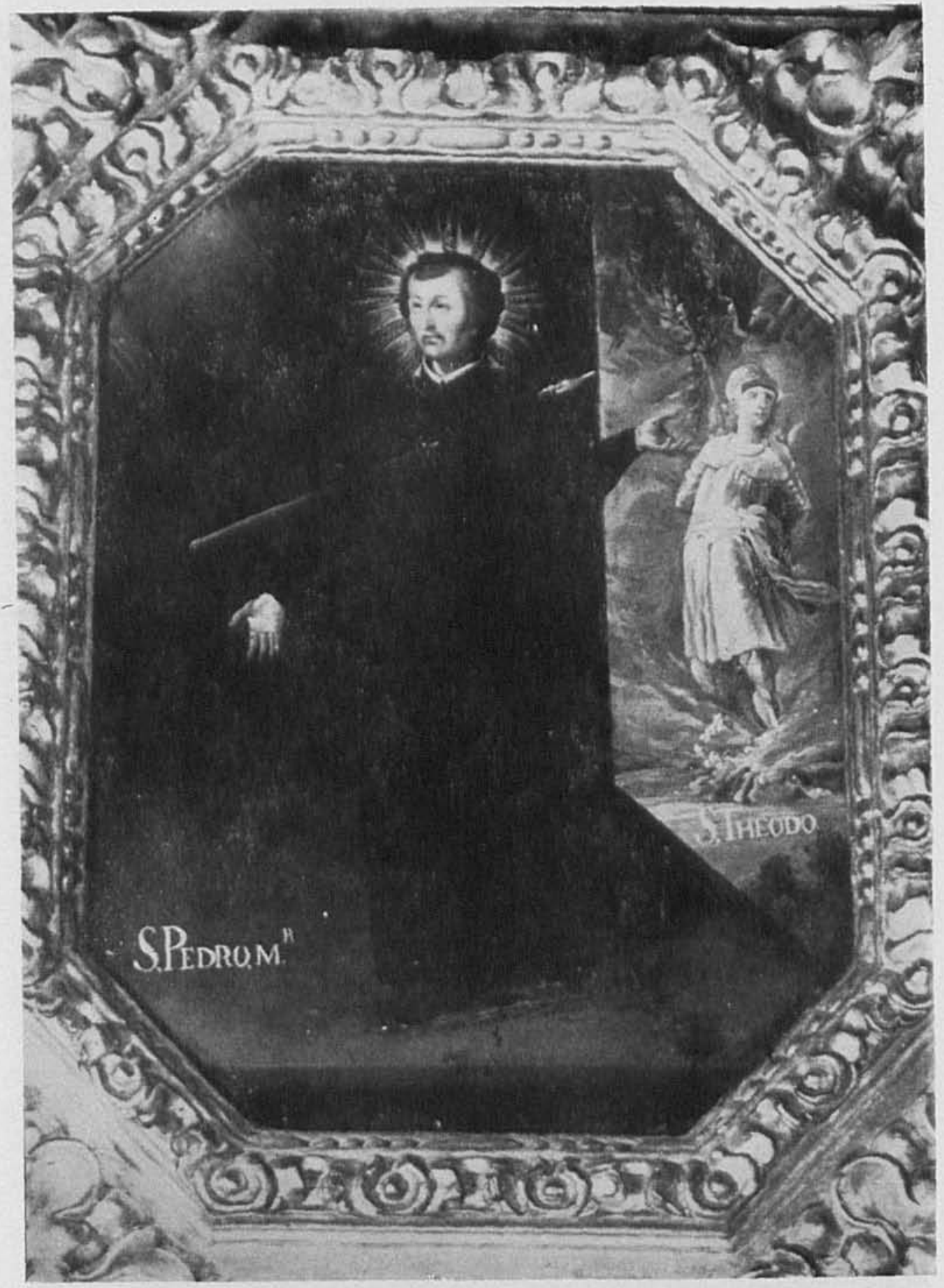

10. San Pedro Mártir. Foto S. March. 
DOI: http://dx.doi.org/10.22201/iie.18703062e.1972.41.963

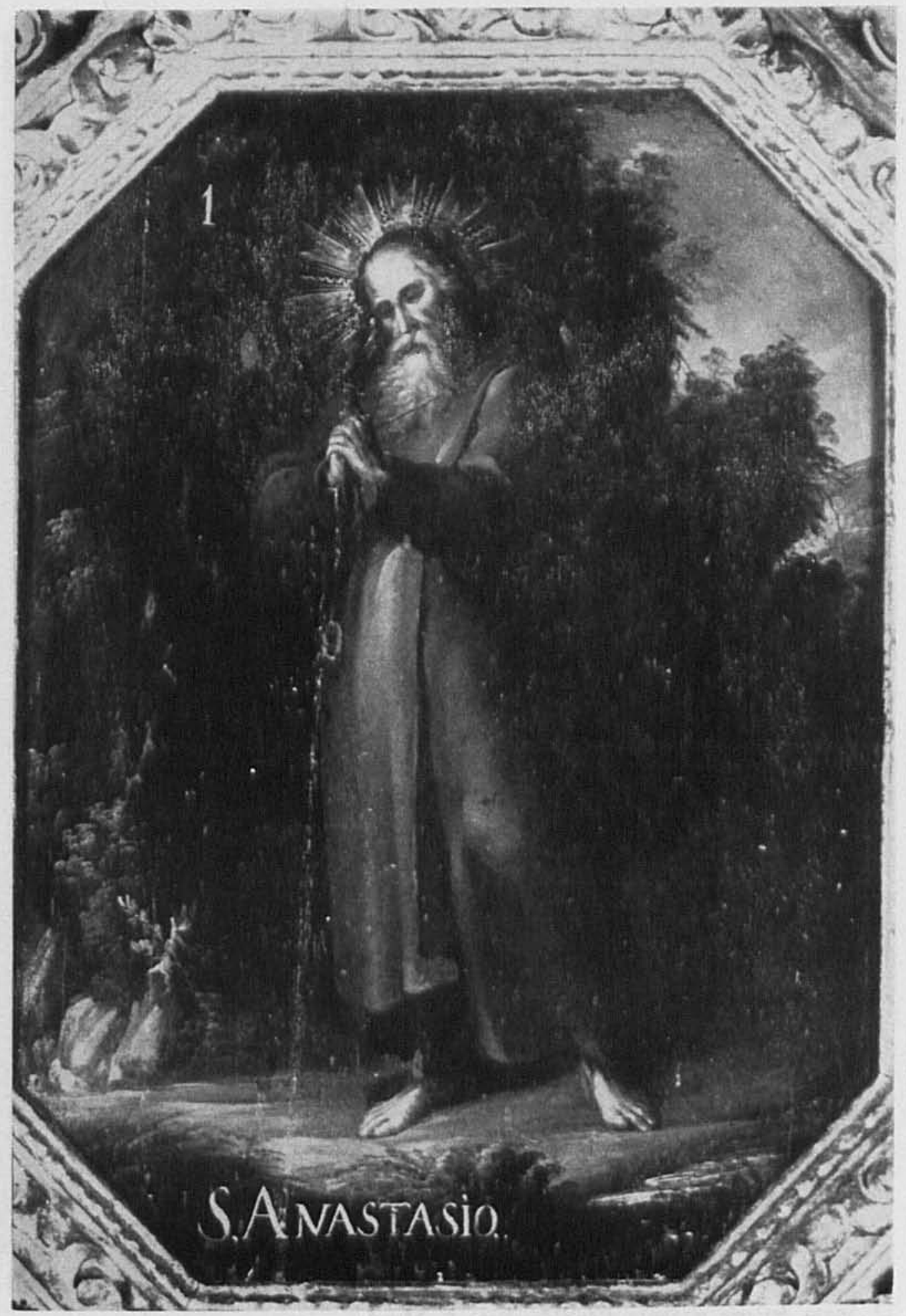

11. San Anastacio. Foto S. March. 


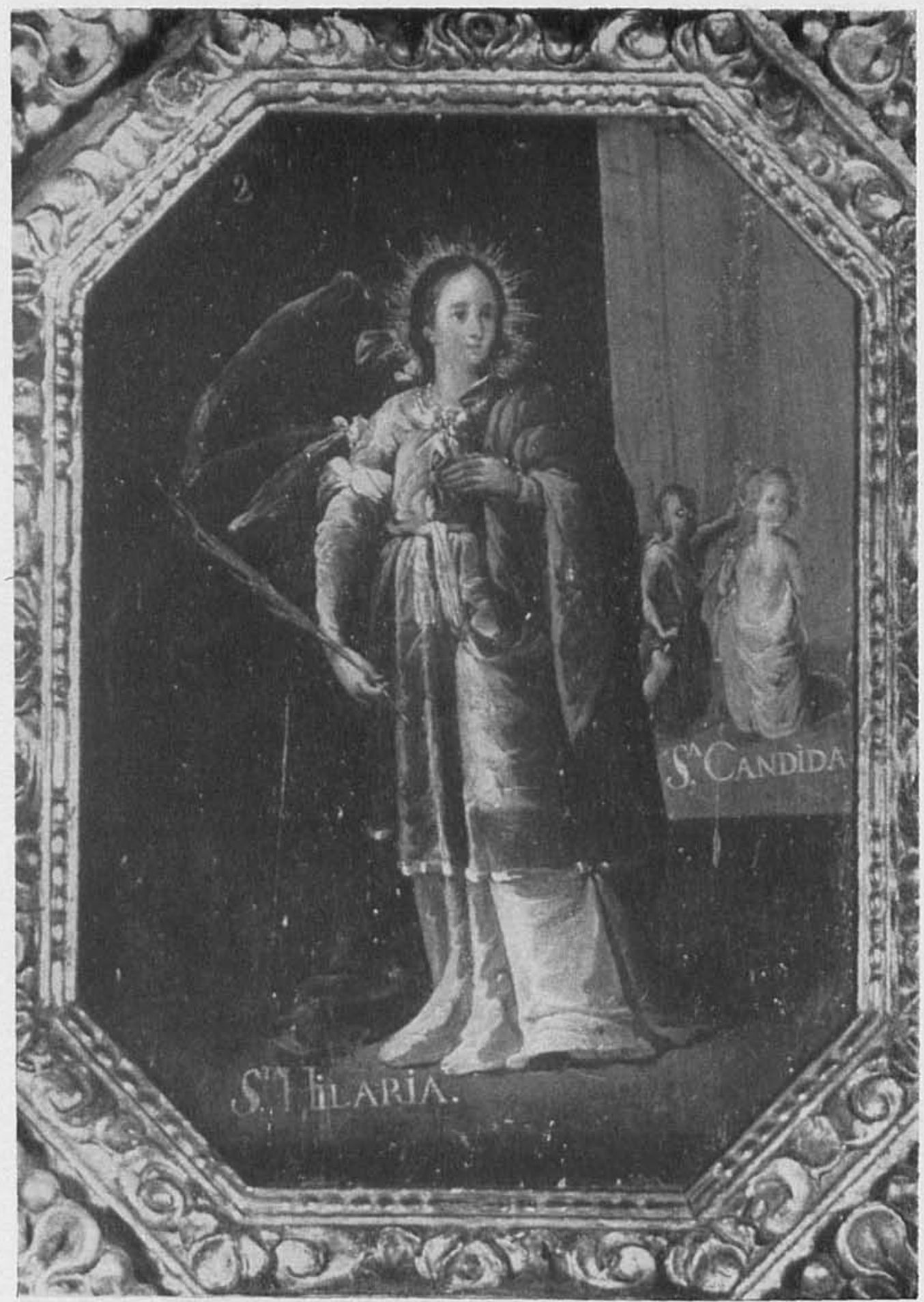

12. Santa Hilaria y Santa Cándida. Foto S. March. 
DOI: http://dx.doi.org/10.22201/iie.18703062e.1972.41.963

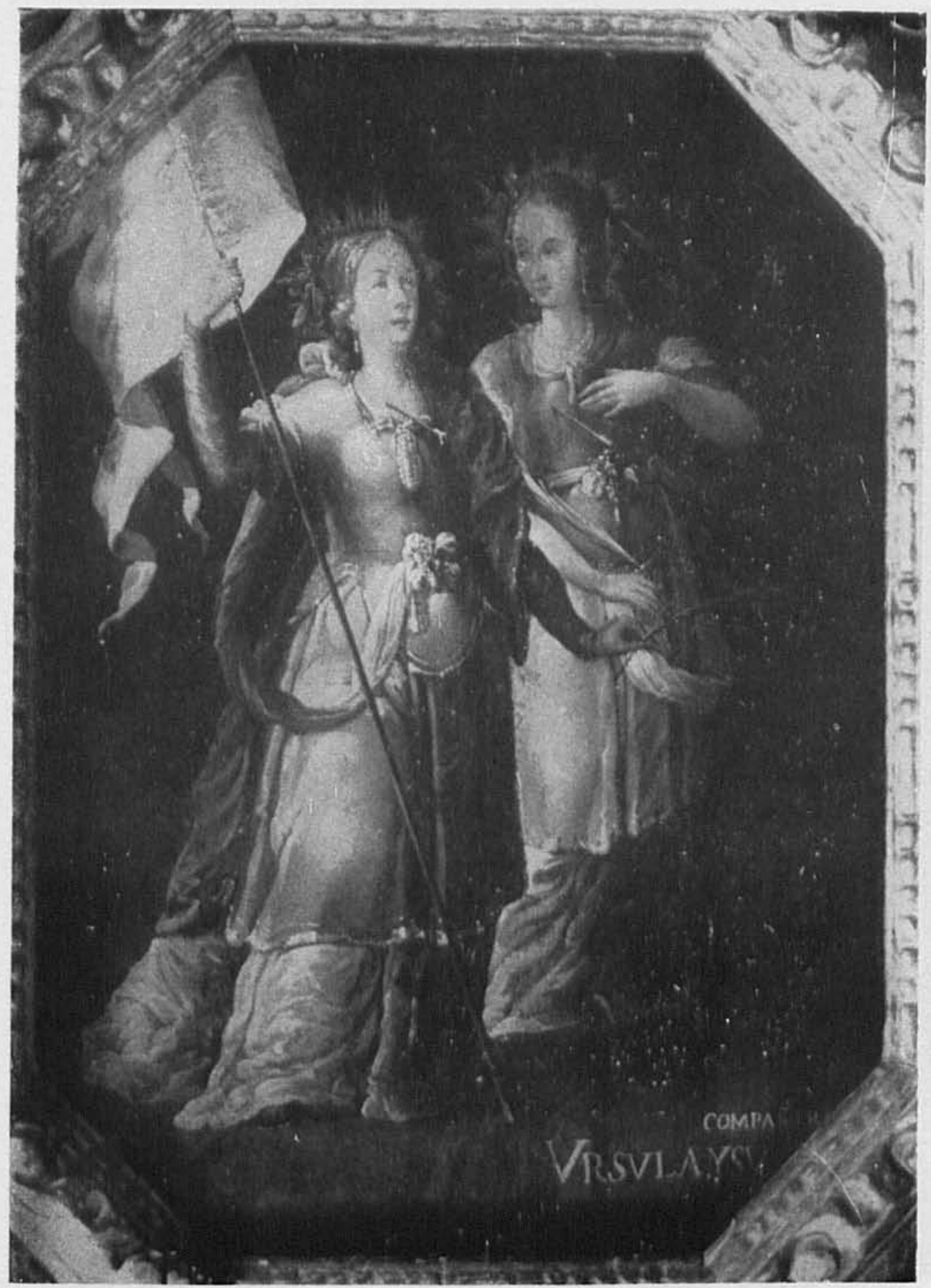

13. Santa Ưrsula y su compañera. Foto S. March. 
DOI: http://dx.doi.org/10.22201/iie.18703062e.1972.41.963

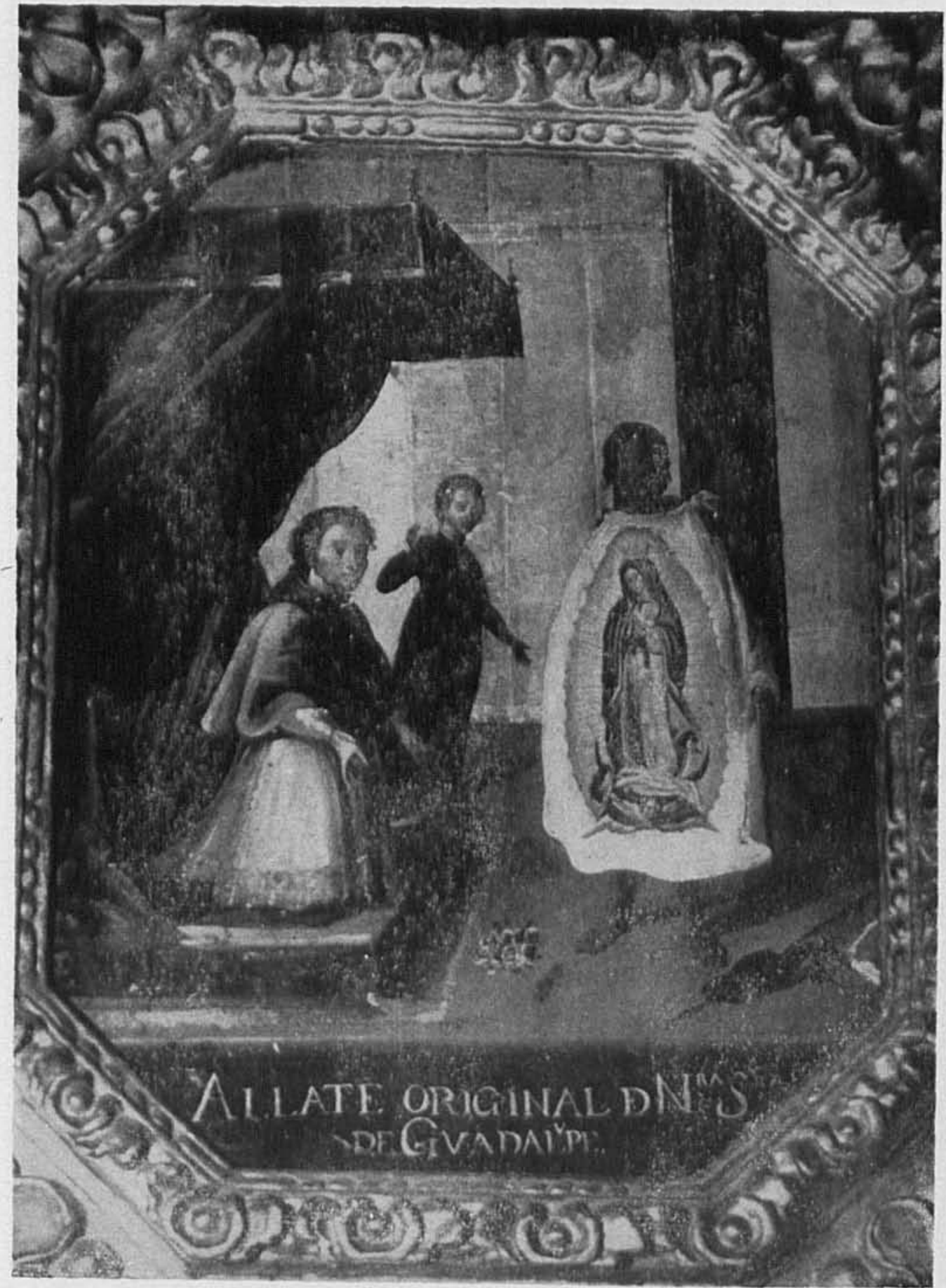

14. El obispo Zumárraga y la Guadalupana. Foto S. March. 


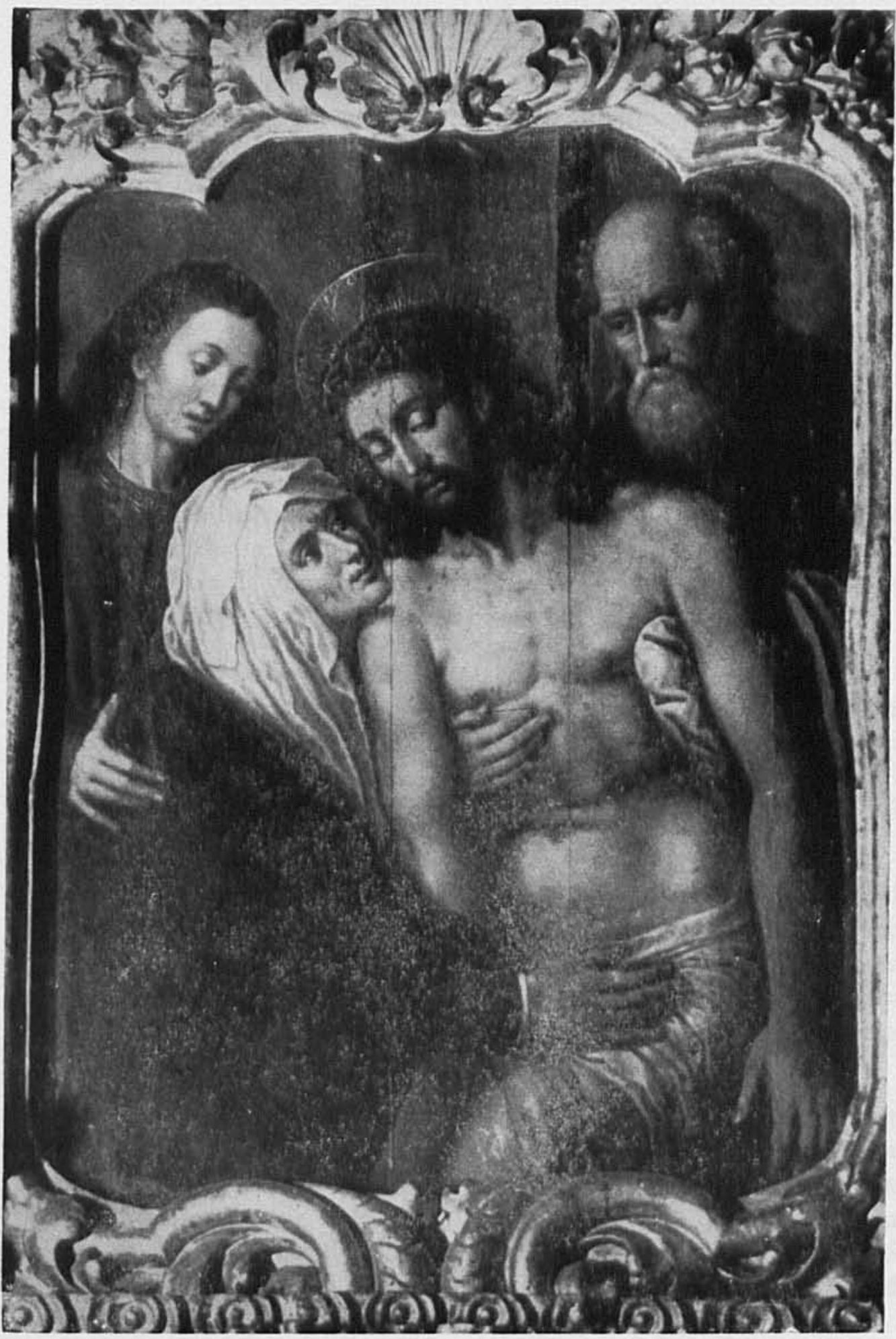

15. Descendimiento. Pintura flamenca. Foto S. March. 
DOI: http://dx.doi.org/10.22201/iie.18703062e.1972.41.963 
este niño prodigio sacó al demonio del cuerpo de ese emperador, fue martirizado, quemando su cuerpo, lentamente, con aceite hirviendo. Sus restos se conservan en la abadía alemana de Corvey.

Herrera lo representa en edad juvenil, con bello y tierno rostro, superando inmóvil y sereno el aceite caliente que el verdugo chorrea sobre su hombro derecho. Está de rodillas, desnudo el torso y envueltos los muslos en una vestidura indefinible que arrastra en el suelo como un manto. Un niño atiza el fuego en que calienta el aceite, figura secundaria pero encantadora, que compone muy bien la escena dentro del negro fondo de su tenebrismo.

6. San Epigmenio. Presbítero mártir también de la persecución de Dioclesiano. Como fue degollado y no quiso repetir Herrera las posturas de San Gelasio o de Gaudencia, éste ya está casi caldo, chorreando sangre, y el verdugo se ensaña con él, verdugo el más elegante de la serie y de más buen vestir. Como en el caso de San Abundio, hay ese rompimiento de la negrura del fondo por medio de un paisaje. Tal vez, para evitar la monotonla y la repetición. Este paisaje puede ser del propio Herrera, pero también puede ser del retocador del xvill.

7. San Felipe de Jestis. Aqui Herrera cambia radicalmente, pues el fondo tenebroso se hace un bonito paisaje de rocas y árboles, lejanías con castillos, nubes y el mar con la nao de la China. El santo mexicano está en la cruz de su martirio, con las dos lanzas que atraviesan su pecho. El sencillo hábito, es de tela gruesa, como lustrosa, de color oscuro.

8. San Pedro Mártir. En las enciclopedias existe un San Pedro, mártir, pero de la Orden Dominicana. No puede ser éste, que es presbitero. Tampoco es San Pedro Arbués, Inquisidor de Cataluña. Viste sotana de clérigo y su martirio consistió en el alanceamiento. Un San Teodoro se cuela en el dudoso rincón. Fue un quemado en tiempos del emperador Maximino.

9. San Anastasio. Monje de la Orden de San Basilio, decapitado en Cesárea en el año de 628. Lleva el número 1 y es el inmediato al altar, en el lado izquierdo. Es un anciano venerable, de barba blanca, nimbado como ninguno de su aureola dorada. EI hábito, como el del San Felipe, es de burda tela parda. Por excepción, emerge de un rincón boscoso, con algo de cielo al fondo. Este cuadro parece que no ha sido cambiado de sitio. 
10. Santa Hilaria. Fue quemada en Augsburgo, Baviera, por llorar y rezar en la tumba de su hija, Santa Afra, mártir también en tiempos de Diocleciano. No está, por fortuna de ella y de nosotros, en el momento del suplicio, sino en glorificación, con sus elegantes vestiduras de brillantes sedas, entre romana y medieval. Es una hermosa dama de limpio y ovalado rostro y ojos negros y vivaces. Al fondo esa intromisión molesta de otra figura, otra mártir, Santa Cándida, semidesnuda por cierto y ante la cual se hinca el verdugo para clavarle una espada.

11. Santa Úrsula y compañera. La curiosa leyenda, como se sabe, nos dice que una princesa británica, prometida en matrimonio a un rey bárbaro, habia hecho voto de castidad, por lo cual huía de su pretendiente haciendo tiempo y dando largas al asunto. Fue a Roma y, a la vuelta para Inglaterra, pasó por Colonia, Alemania, donde fue decapitada por los hunos. Como la acompañaban 11,000 vírgenes compañeras, todas sucumbieron. Parece que la fábula nace de una mala lectura epigráfica: de XI.M.V. "once mil vírgenes", por "once mártires vírgenes". Para el arte ha sido fecunda, desde la basilica de Colonia y las pinturas venecianas de Carpaccio, hasta Rubens.

Herrera, ante el minúsculo tamaño de su tabla, se decidió a pintar a la santa con una sola compañera. Son ambas vírgenes dos hermosas damas, de amplios y ricos vestidos. Úrsula enarbola una larga bandera que ondula con el viento y capta esa luz que el tenebrismo daba a sus tiguras sin que pasara de ellas Las aureolas, son, por excepción, pequeñas.

12. Juan Diego ante Zumárraga. Ya se dijo que esta pintura no es ni de Herrera ni original. Es del autor de los letreros. El indio, casi negro, muestra el "ayate" al joven obispo Zumárraga a la manera tradicional, es decir, del siglo xvIII.

Aprovecho este ensayo para dar a conocer otra pintura que existe en el retablo mayor de la Capilla de las Reliquias. Me refiero al Descendimiento, cuadro flamenco, citado de paso, nunca estudiado y valorizado, ignorado, en realidad, por historiadores y críticos. Cierto es que la pintura europea existente en México no ha sido estudiada como se merece. Sea la que se conserva en el Museo de San Carlos; sea la poca 
que hay en las iglesias; sea la de colecciones particulares, la mayoría inaccesibles, el caso es que los escritos sobre esa pintura se cuentan con los dedos. No sabemos - ni los dueños quieren que se sepa- la cantidad y calidad de pintura europea existente en México, salvo la colección mencionada del Museo de San Carlos, dudosa cual ninguna.

En los libros o artículos sobre la Catedral de México se dicen cosas como éstas: "En la puerta del nicho central del altar, hay una pintura del Descendimiento y dentro está el cuerpo de San Teófilo mártir." (Marroqui.) "La pintura del Descendimiento cubre una bellísima urna de bronce dorado y cristales (que) contienen el esqueleto completo de San Teófilo mártir." (Sandoval.) La "bellísima" fue la urna, no la pintura.

$Y$ es muy extraño que el eminente maestro e historiador de Arte Colonial, sobre todo de la pintura, Manuel Toussaint, no haya dicho nunca una palabra sobre esta obra de arte tan notable. La olvidó en su ensayo El arte flamenco en Nueva España, 1949 y, más extraño aún, en su magno libro sobre La Catedral de México. Ni siquiera una mención de paso hay en su capítulo sobre la Capilla de las Reliquias, ocupando en hablarnos en demasía de los restos del famoso Gregorio López y del padre Francisco Losa, que allí reposan.

He lefdo, no recuerdo dónde, que es un Tiziano. Como es un honorable disparate, no me detengo en ello.

En realidad es una copia de un cuadro perdido de Roger van der Weyden. Así lo aseguran los eminentes especialistas en arte flamenco, el profesor Lavallege y Micheline Sonkes, presidente y secretario del Centro Nacional de Investigaciones de Primitivos flamencos, de Bruselas. ${ }^{8}$ Hay muchas copias de ese original de Van der Weyden. Nuestra copia parece ser del siglo xvi.

La escena es la clásica. El cuerpo de Cristo acaba de ser bajado de la cruz. Lo sostiene Nicodemo. Nada veraz resulta la postura, pues un cadáver no sostiene ni el torso ni la cabeza erguidos con tan poco apoyo. Pero eso es lo de menos. Es el Cristo un hermoso varón de incipiente madurez, con la barba y el cabello negros. El torso es de excelente dibujo y bellas formas, de suaves curvas en los hombros, pero los muslos, en verdad, son defectuosos por cortos.

La Virgen no sabe colocar bien su mano derecha, pero su cabeza es magnifica, envuelta en los típicos velos blancos de las matronas de

8 Carta particular del 5 de noviembre de 1970. 
Flandes. El San Juan, figura secundaria, sostiene a la Madre y llora una lágrima que se inmoviliza en su mejilla. El Nicodemo es la mejor figura. La nobilísima cabeza del anciano es soberbia, pintada con todo esmero y de exquisito dibujo. Notemos, por último, la aureola del Cristo, que es como de fino cristal, sobre la corona de espinas. El cuadro fue recortado en el siglo xviri para meterlo en el actual marco.

Olvidemos esta barbarie y gocemos la limpia belleza de los personajes de este Descendimiento flamenco. 